Jurnal Inkofar * Volume 1 No. 1, Juli 2018 * ISSN: 2615-3645 (Print) / 2581-2920 (Online)

Tersedia secara online di: http://www.politeknikmeta.ac.id/meta/ojs/

\title{
PERANCANGAN VISUAL PLANNING (VP) UNTUK PERBAIKAN PENCAPAIAN QUALITY OBJECTIVE (QO) DI DIREKTORAT PRODUKSI PT. KRAKATAU WAJATAMA
}

\author{
Untung Mardono $^{1}$, Zulfa Fitri Ikatrinasari ${ }^{2}$ \\ ${ }^{1}$ Magister Teknik Industri / Fakultas Teknik Industri / Universitas Mercu Buana / \\ u_mardono@yahoo.co.id \\ ${ }^{2}$ Dosen Magister Teknik Industri / Pasca Sarjan / Universitas Mercu Buana / \\ zulfa.fitri@mercubuana.ac.id
}

\begin{abstract}
Performance of PT. Krakatau Wajatama as one of the Long Products steel processing company is influenced by External factors namely US Dollar Exchange, Domestic steel demand, and Internal factor is the cost of production. The cost of the production process (rolling cost) is composed of costs: energy, labor, roll costs and maintenance costs are all controlled by the Production Directorate, which is described in 3 (three) Divisions namely Production, Maintenance and Production Planning \& Raw Material Control. The KPI (Key Performance Indicator) of the Production Directorate is defined as the target and job target of each Division in the form of Quality Objective (QO) reported per month and evaluated through Management Review every 3 (three) months. The realization of the achievement of QO targets every month will show the level of efficiency of production processes that affect the cost of products (HPP), product competitiveness and sales volume realization. In 2017 the production volume target of Steel rebars is 142,000 tons and Steel profile is 91,500 tons, with realization achievement of only $47 \%$ and $41 \%$. Based on the evaluation of the realization of the achievement of the $\mathrm{QO}$ of all Divisions within the Directorate of Production is only achieved by $40 \%$, one of the factors causing the low achievement of QO is the lack of frequency and effectiveness in evaluating the achievement of QO. With the implementation of Visual Planning (VP) done in konsinten, the implementation of the work program will be better and the level of achievement QO will increase.
\end{abstract}

Keywords: Key Performance Indicator, Quality Objective, Visual Planning

\begin{abstract}
ABSTRAK
Kinerja PT. Krakatau Wajatama sebagai salah satu perusahaan pengolahan baja Long Product dipengaruhi oleh faktor Ekternal yaitu Kurs Dolar Amerika, kebutuhan baja domistik, dan faktor Internal yaitu biaya produksi. Biaya proses produksi (rolling cost) tersusun atas biaya : energi, tenaga kerja, biaya roll dan biaya perawatan yang semuanya dikendalikan oleh Direktorat Produksi, yang dijabarkan dalam 3 (tiga) Divisi yaitu Produksi, Perawatan dan Perencanaan Produksi \& Pengendalian Bahan Baku. KPI (Key Performance Indicator) Direktorat Produksi dijabarkan menjadi target dan sasaran kerja pada masingmasing Divisi dalam bentuk Quality Objective (QO) yang dilaporkan pencapaiannya setiap bulan dan dilakukan evaluasi melalui Tinjauan Manajemen setiap 3 (tiga) bulan. Realisasi pencapaian target QO setiap bulannya akan menunjukkan tingkat efisiensi proses produksi yang mempengaruhi harga pokok produk (HPP), daya saing produk dan realisasi volume penjualan. Pada tahun 2017 target volume produksi Baja Tulangan sebesar 142.000 ton dan Baja profil sebesar 91.500 ton, dengan realisasi pencapaian hanya sebesar $47 \%$ dan $41 \%$. Berdasarkan evaluasi realisasi pencapaian QO seluruh Divisi di lingkungan Direktorat Produksi hanya tercapai sebesar $40 \%$, salah satu faktor yang menyebabkan rendahnya
\end{abstract}


pencapaian QO adalah kurangnya frekwensi dan efektifitas dalam melakukan evaluasi pencapaian QO. Dengan Implementasi Visual Planning (VP) yang dilakukan secara konsinten, pelaksanaan program kerja akan menjadi lebih baik dan tingkat pencapaian QO akan meningkat.

Kata Kunci : Key Performance Indicator, Quality Objective, Visual Planning

\section{PENDAHULUAN}

PT. Krakatau Wajatama merupakan salah satu anak perusahaan PT. Krakatau Steel, Cilegon Banten yang merupakan pionir Rolling Mill Baja Batangan di Indonesia dengan kapasitas produksi produk Baja Tulangan dan Baja Profil masing-masing sebesar 150.000 ton per tahun. Untuk menjaga konsistensi kualitas produk dan service, perusahaan telah menerapkan sistem manajemen mutu ISO 9001 : 2015 dan ISO 14000 sehingga menjadikan produkproduk PT. Krakatau Wajatama tetap menjadi acuan akan kualitas produk baja di Indonesia. Pada era perdagangan bebas saat ini eksistensi sebuah perusahaan khususnya perusahan baja tidak cukup dengan hanya memiliki kekuatan brand image yang kuat, tetapi harus dapat memberikan produk yang berkualitas dengan harga kompetitif dan mampu bersaing di pasar. Menurut Statistical Yearbook SEAISI (2016) kapasitas produksi Pabrik Baja Profil nasional sebesar 2,41 juta ton dan kebutuhan nasional sebesar 1,02 juta ton, sedangkan kapasitas produksi Baja Tulangan nasional sebesar 7,54 juta ton dan kebutuhan nasional sebesar 2,55 juta ton. Dengan data tersebut artinya ada ketidakseimbangan antara supply dan demand produk baja di Indonesia, sehingga berdampak pada strategi operasi yaitu utilisasi kapasitas produksi dari setiap pabrik rata-rata dibawah $50 \%$. Hal ini menyebabkan operasional proses produksi tidak efisien dan biaya produksi tinggi.

Tantangan industri baja profil dalam negeri semakin berat dengan adanya perjanjian perdagangan bebas China-Asean (CAFTA) dan menuntut pabrik-pabrik baja nasional termasuk PT. Krakatau Wajatama harus terus melakukan langkah-langkah perbaikan untuk menghasilkan produk yang berkualitas dengan biaya produksi yang efisien agar dapat bersaing dengan produk-produk kompetitor termasuk produk baja impor. Untuk menghadapai berbagai tantangan diatas PT. Krakatau Wajatama dituntut untuk melakukan perbaikan internal proses dengan tujuan meskipun fasilitas produksi tertinggal dengan teknologi fasilitas produksi kompetitor, namun tetap dapat menghasilkan produk baja dengan kualitas yang baik dengan harga yang dapat bersaing di pasar.

Kinerja PT. Krakatau Wajatama dipengaruhi oleh faktor Ekternal yaitu Kurs Dolar Amerika sebagai dampak atas $95 \%$ bahan baku import dan faktor Internal yaitu Biaya produksi. Biaya proses produksi (rolling cost) tersusun atas biaya : energi, tenaga kerja, roll dan biaya perawatan yang semuanya dikendalikan oleh Direktorat produksi.

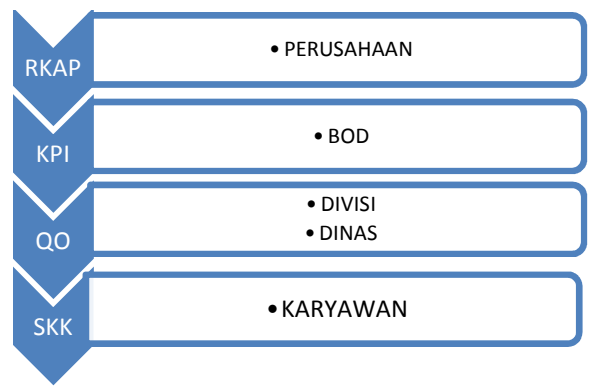

\section{Gambar 1.1 Penjabaran Target Kinerja}

Untuk mendukung pencapaian kinerja perusahaan sesuai Rencana Kerja dan Anggaran Perusahaan (RKAP) setiap tahun telah dilakukan penjabaran Key Performance Indicator (KPI) perusahaan menjadi Quality Objective (QO), Satuan Kerja Karyawan (SKK). Semua target-terget tersebut dilakukan evaluasi dalam bentuk laporan pencapaian QO pada setiap 
bulannya dan melaluai Tinjauan Manajemen setiap 3 (tiga) bulan. Penjabaran target-target tersebut dapat digambarkan pada gambar 1.1 berikut :

Sesuai dengan RKAP tahun 2017 Direktorat Produksi ditargetkan dapat mencapai volume produksi sebesar 142.000 ton untuk Baja Tulangan dan 91.500 ton Baja profil disertai dengan biaya proses produksi (rolling cost) yang efisien. Biaya produksi tersusun atas biaya energi, biaya tenaga kerja, biaya roll dan biaya perawatan. Berbagai parameter penyusun rolling cost tersebut dijadikan sebagai target QO pada level-level dibawahnya. Realisasi pencapaian volume produksi pada tahun 2017 hanya tercapai sebesar $47 \%$ dan $41 \%$. Tidak tercapainya volume produksi disebabkan oleh faktor-faktor berikut :

1. Ekternal yaitu Harga bahan baku, realisasi proyek-proyek pemerintah dan produk impor.

2. Internal yaitu Kerusakan peralatan, Tingginya frekwensi couble.

Faktor-faktor internal tersebut tercermin dalam realisasi pencapaian QO dari seluruh Divisi dan Dinas di lingkungan Direktorat Produksi seperti pada gambar 1.2 berikut :

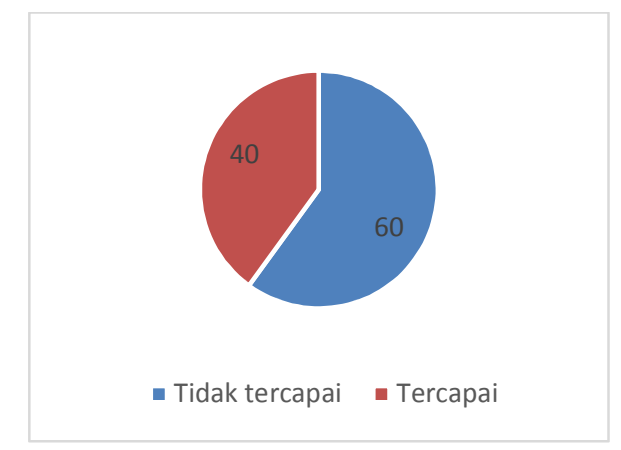

Gambar 1.2 Realisasi Pencapaian QO

Salah satu faktor yang menyebabkan rendahnya pencapaian QO adalah kurangnya frekuwensi dan efektifitas dalam melakukan evaluasi pencapaian QO.

Dengan latar belakang tersebut diatas mendorong peneliti untuk merancang sistem perbaikan kinerja dengan Implementasi Visual Planning (VP).

\section{TINJAUAN PUSTAKA}

\subsection{Keterkaitan Manajemen dan Rencana Strategis Perusahaan}

Menurut Aguinis (2008) Perencanaan strategis sebuah organisasi harus dapat dijabarkan dan digunakan secara efektif sebagai bagian dari sistem manajemen kinerja. Tidak sedikit organisasi yang mengahabiskan banyak waktu untuk membuat rencana strategis tetapi tanpa ditindaklanjuti dengan tindakan konkrit. Oleh karena itu, untuk memastikan bahwa strategi dijabarkan hingga level terendah di organisasi dan mendorong tindakan konkrit diperlukan upaya untuk mengaitkan rencana strategis dengan kinerja individu.

Pada gambar 5.1 memberikan kerangka kerja keterkaitan antara rencana strategi organisasi, rencana strategi unit, job description, serta kinerja individu dan tim. Rencana strategis organisasi termasuk pernyataan misi dan visi, serta tujuan dan strategi untuk mencapai misi dan visi. Strategi dihasilkan dari partisipasi seluruh level manajer. 
Jurnal Inkofar * Volume 1 No. 1, Juli 2018 * ISSN: 2615-3645 (Print) / 2581-2920 (Online)

Tersedia secara online di: http://www.politeknikmeta.ac.id/meta/ojs/

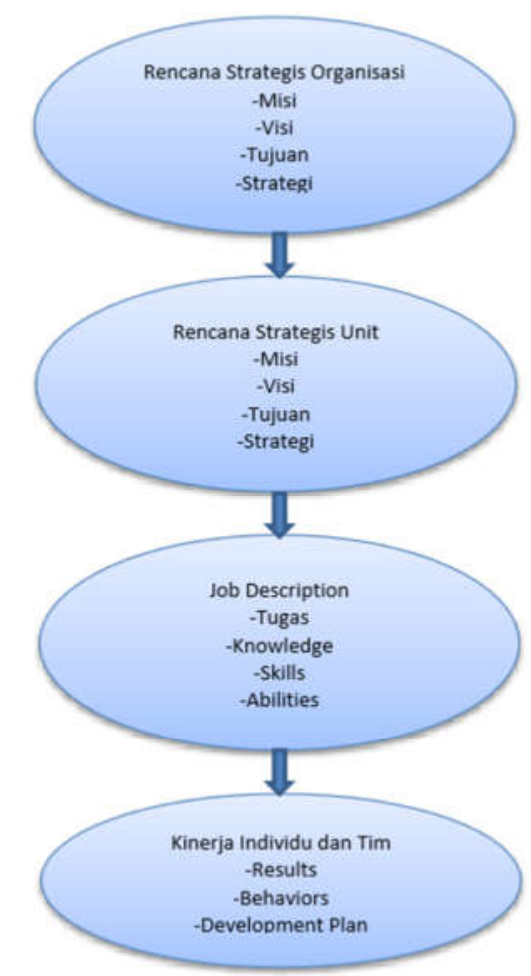

\section{Gambar 5.1 Keterkaitan Rencana Strategis sampai Kinerja Individu (Sumber : Anguinis,2008)}

\subsection{Key Performance Indicators (KPI)}

Menurut Anguinis (2008) KPI memiliki peran penting bagi kemajuan sebuah perusahaan. Sebab, perusahaan akhirnya dituntut memiliki visi dan misi yang jelas serta langkah praktis untuk merealisasikan tujuannya. Dan tidak sekedar itu saja, dengan KPI perusahaan bisa mengukur pencapaian performa kinerjanya. Apakah sudah sesuai ataukah belum sama sekali. Karena KPI merupakan alat ukur performa kinerja sebuah perusahaan, maka KPI juga harus mencerminkan tujuan yang ingin diraih oleh perusahaan tersebut. Artinya, KPI setiap perusahaan bisa jadi berbeda sesuai dengan kebutuhannya.

Oleh karena itu sebelum menetapkan KPI, perusahaan harus melakukan beberapa persiapan berikut ini:

1. Menetapkan tujuan yang hendak dicapai.

2. Memiliki bisnis proses yang telah terdefinisi dengan jelas.

3. Menetapkan ukuran kuantitatif dan kualitatif sesuai dengan tujuan yang hendak dicapai.

4. Memonitor setiap kondisi yang terjadi serta melakukan perubahan yang diperlukan guna mencapai tujuan yang telah ditetapkan, baik tujuan jangka pendek maupun tujuan jangka panjang.

Agar KPI bisa berfungsi dengan optimal, maka KPI harus memenuhi kaidah SMART. Yakni Specific (spesifik), Measureable (terukur), Achievable (bisa dicapai/realistis), Reliable (bisa dipercaya), Time bound (target waktu).

\subsection{Visual Planning (VP)}

Lindlöf, L. \& Söderberg, B. (2011) VP merupakan methode yang relatif baru yang salah satu sasarannnya bertujuan untuk meningkatkan komunikasi diantara anggota team menjadi lebih effisien, VP dirancang melalui menejemen Visual, yang berdasarkan pada ilmu tingkah laku 
manusia (behavioral science), jadi fokusnya ke masalah manusia-nya bukan ke masalah teknologi.

Min, K.Z. (2010) VP bertujuan merubah metode cara bekerja untuk kepentingan meningkatkan performansi dan kinerja Perusahaan, menyelaraskan tugas-tugas individual sesuai Visi, Misi perusahaan, membuat setiap individu berpartisipasi dalam meminimalisasi pekerjaan yang tidak berguna terutama yang tidak mendatangkan nilai tambah bagi perusahaan, atau VP bisa dikatakan juga sebagai pembunuh rumor (rumour killer).

Josefin, B. and Gunilla, W. (2015) VP merupakan suatu metode atau alat untuk memvisualkan perencanaan dimana komunikasi dan transfer pengetahuan memegang peran penting. Penerapan VP, akan lebih menumbuhkan lingkungan yang saling mempercayai, saling berkolaborasi untuk mengkoreksi kesalahan, berdiskusi secara terbuka tentang permasalahan dan halangan pencapaian target.

Menurut Ronald Mascitelli (2011) Kunci pertemuan berdiri yang sukses dalam VP adalah singkat dan dengan jumlah tim yang lengkap. Jika durasi melebihi lima belas menit dapat menyebabkan tujuan pertemuan itu hilang, orang bisa merasa tidak nyaman dan dapat berhenti fokus pada pertemuan. Aspek lain yang perlu dipertimbangkan adalah waktu pertemuan. Waktu pertemuan pada pagi hari lebih positif, karena setiap orang biasanya tiba di kantor pada waktu dan waktu yang sama.

Min, K.Z. (2010) VP merupakan style menejemen yang berorientasi pada proses (Process Oriented) dan cara tepat untuk melakukan perubahan secara on-going dan continous, bekerja effisien, dalam meningkatkan produktivitas dan laba perusahaan. Proses implementasi dari VP seperti ditunjukkan pada gambar 2.2 berikut :

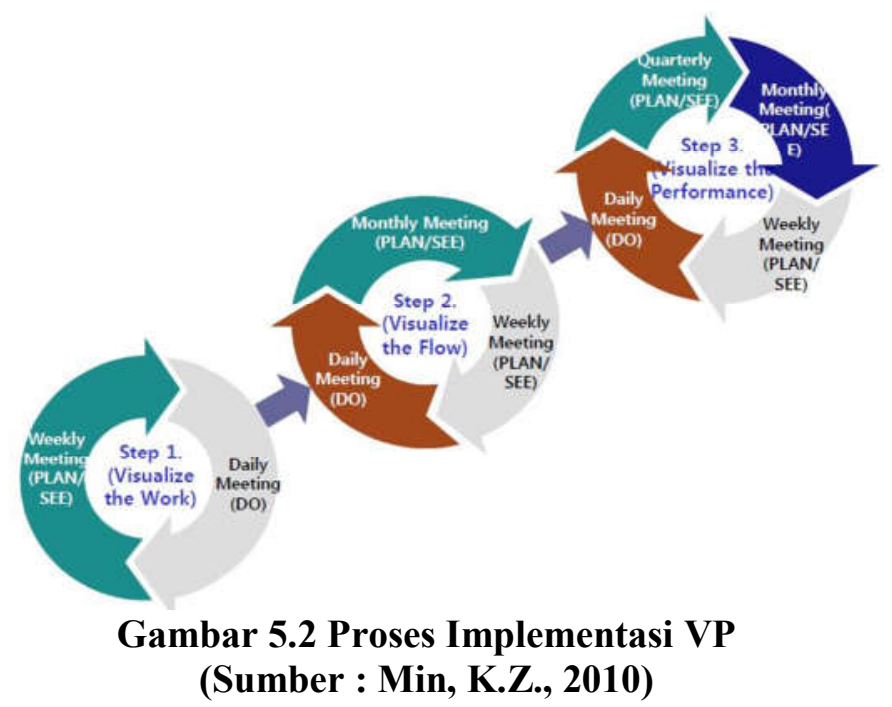

Menurut Min, K.Z. (2010) beberapa keuntungan dengan menerapkan metode VP :

1. Di depan papan VP para anggota setiap harinya bisa mem-visualisasikan target-target dan aktivitas-aktivitas dari setiap unit kerja/organisasi maupun personal yang sangat berkaitan dengan Misi dan Visi perusahaan.

2. Para manejer dapat langsung meniadakan aktivitas yang tidak bermanfaat untuk perusahaan, dan juga langsung bisa melakukan pengecekan apakah suatu tugas terencana atau tidak terencana (planned/unplanned)

3. Para manejer diminta mempraktekkan koordinasinya layaknya seorang pimpinan orkestra yang mengarahkan target-target sequensial atau cascading secara tepat, dan memimpin penyelesaian tugas yang interdependent 
4. Mendapatkan pencapaian maximal atas persoalan yang mempunyai faktor-faktor kesuksesan yang kritis, baik yang berhubungan secara internal maupun external.

5. Para anggota team selalu dapat menciptakan suasana yang terciptanya saling percaya, melalui aktifitas-aktifitas hubungan sosial, seperti merayakan ulang tahun atau ulang tahun perkawinan, yang merupakan suatu bumbu penyedap terpeliharanya Team-Work.

6. Manejer yang mempunyai percaya diri yang tinggi tanpa memanfaatkan VP, hanya akan menjadi Manejer yang banyak berbicara (talk more) tanpa bisa mengaktualisasikan perencanaannya, tetapi manejer yang mempunyai percaya diri yang tinggi dan memanfaatkan VP akan menjadi manejer yang effisien dan selalu berprestasi dalam situasi yang sulit, sanggup tersenyum dalam situasi kritis, berargumen dalam diskusi, secara bersamaan juga bisa mengajak para anggotanya untuk memecahkan setiap masalah yang kritis.

\section{RANCANGAN VP DIREKTORAT PRODUKSI}

KPI dari Direktur Produksi sebagai acuan penjabaran target QO pada level Divisi dan Dinas seperti pada table 3.1 berikut :

Table 3.1 Tabel KPI Direktur Produksi

\begin{tabular}{|l|c|c|}
\hline \multicolumn{1}{|c|}{ Pabrik } & $\begin{array}{c}\text { Volume } \\
\text { Produksi (Ton) }\end{array}$ & $\begin{array}{c}\text { Rolling Cost } \\
\text { (Rp./kg) }\end{array}$ \\
\hline Baja Tulangan & 142000 & 750 \\
\hline Baja Profil & 91500 & 1750 \\
\hline
\end{tabular}

KPI tersebut dijabarkan pada level Divisi dan Dinas seperti pada table 3.2 berikut :

Table 3.2 Deploy KPI Divisi-Dinas

\begin{tabular}{|c|c|}
\hline Divisi / Dinas & Jumlah QO \\
\hline & \\
\hline Divisi Produksi & 8 \\
\hline Dinas Pabrik Baja Tulangan & 4 \\
\hline Dinas Pabrik Baja Profil & 5 \\
\hline Dinas Bengkel Roll \& Guide & 6 \\
\hline Divisi Perawatan & 6 \\
\hline Dinas Perenc. Perawatan & 4 \\
\hline Dinas Perawatan Listrik & 2 \\
\hline Dinas Perawatan Mekanik & 2 \\
\hline Divisi PK \& PTP & 4 \\
\hline Dinas PP \& BB & 4 \\
\hline Dinas PK & 4 \\
\hline
\end{tabular}

Design Papan Visual yang perlu disiapkan :

1. Papan visual utama Direktur Produksi, berisi :

- $\quad$ KPI Direktur Produksi

- $\quad$ Papan Visual Pribadi Dir. Produksi

- $\quad$ Papan visual 3 Divisi

2. Papan visual utama Divisi Produksi, berisi :

- QO Divisi Produksi

- Papan Visual Pribadi Div. Produksi

- Papan visual 3 Dinas

- Papan visual Kepala Seksi 
Jurnal Inkofar * Volume 1 No. 1, Juli 2018 * ISSN: 2615-3645 (Print) / 2581-2920 (Online)

Tersedia secara online di: http://www.politeknikmeta.ac.id/meta/ojs/

3. Papan visual utama Divisi Perawatan, berisi :

- QO Divisi Perawatan

- Papan Visual Pribadi Div. Perawatan

- Papan visual 3 Dinas

- $\quad$ Papan visual Kepala Seksi

4. Papan visual utama Divisi PK \& PTP, berisi :

- $\quad$ QO Divisi PK \& PTP

- $\quad$ Papan Visual Pribadi Div. PK \& PTP

- Papan visual 2 Dinas

- $\quad$ Papan visual Kepala Seksi

Contoh hasil rancangan papan visual dari visual planning Direktorat Produksi terlihat pada gambar 3.1 dan tabel 3.3 berikut :

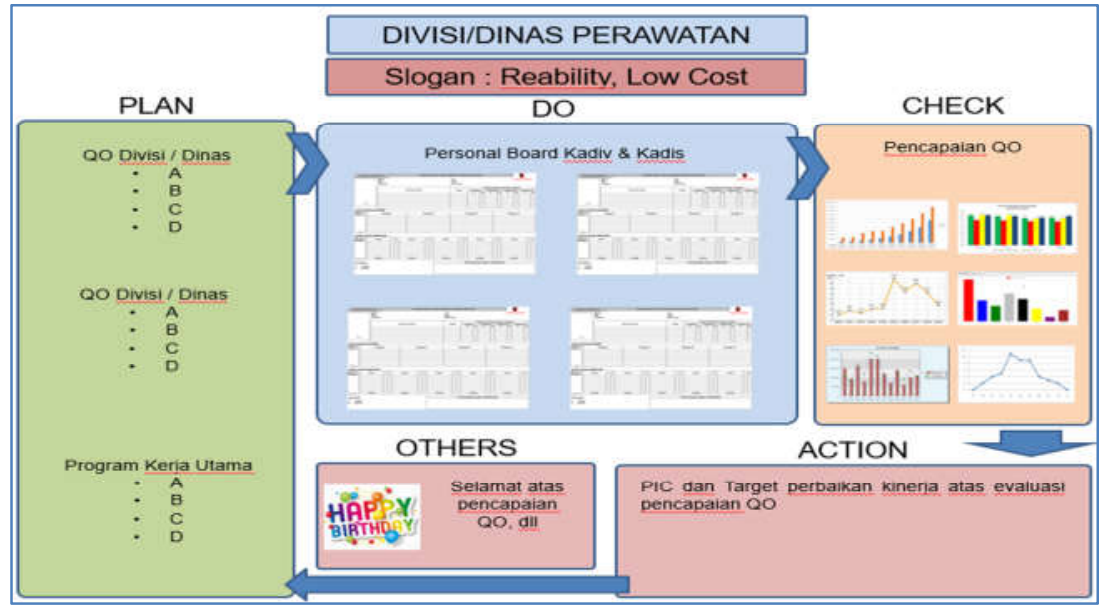

Gambar 3.1 Form papan visual utama Divisi Perawatan

Dan salah satu contoh dari form papan visual dari rancangan visual planning ditunjukkan pada tabel 3.3 berikut :

Tabel 3.3 Form papan visual pribadi

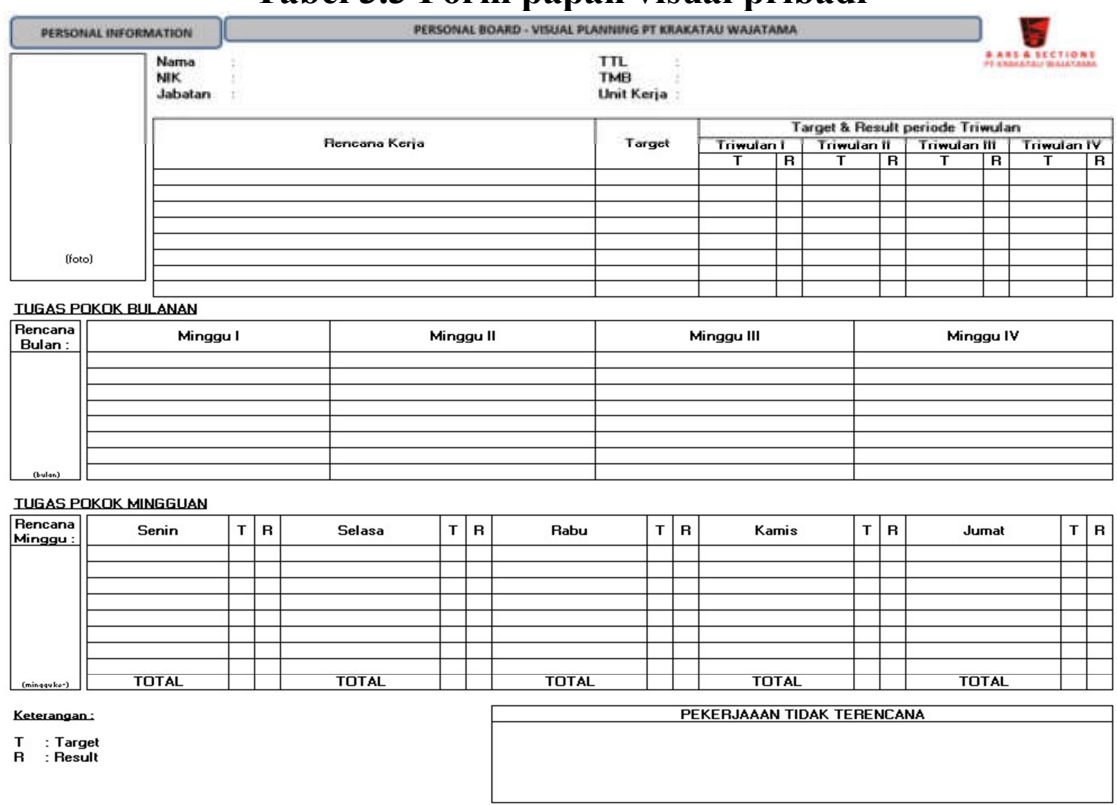


Jurnal Inkofar * Volume 1 No. 1, Juli 2018 * ISSN: 2615-3645 (Print) / 2581-2920 (Online)

Tersedia secara online di: http://www.politeknikmeta.ac.id/meta/ojs/

\section{Implementasi VP}

Langkah-langkah implementasi sebagai berikut :

1. Papan visual utama diisi semua informasi terkait dengan :

- Plan : Sasaran kerja / Quality Objective, Program kerja utama, Program Investasi,

- Do

: Program kerja individu, target, realisasi harian, bulanan, kwartal 1, kwartal 2 dan kwartal 3

- Check : Realiasai dan gap pencapaian QO

- Action : Tindakan perbaikan yang akan dilakukan dan PIC-nya.

2. Rapat harian dilakukan 15 menit sebelum jam masuk kerja dan 15 menit sebelum pulang kerja, dengan berdiri melingkar didepan papan visual yang dipimpin oleh 1 karyawan secara bergantian. Dimana dilakukan secara serentak pada semua level dengan peserta :

- Level Divisi : Divisi terkait/yang mewakili dan 1 orang perwakilan dari masing-masing Dinas.

- Level Dinas : Dinas terkait/yang mewakili dan 1 orang perwakilan dari masing-masing Kepala Seksi

- Level Kepala Seksi : Kepala Seksi terkait/yang mewakili dan seluruh Kepala Regu dibawah Seksi tersebut

3. Rencana kerja pribadi untuk 1 minggu kedepan diisi pada jum'at sore.

4. Realisasi rencana kerja harian diupdate dan dievaluasi oleh masing-masing serta didiskusikan pada rapat harian.

\section{KESIMPULAN DAN SARAN}

Dengan rancangan visual planning yang telah dibuat dan diimplementasikan secara konsisten sesuai dengan langkah-langkah implementasi diharapkan dapat meningkatkan tingkat pencapaian QO pada Direktorat Produksi yang akan memberikan dampak terhadap :

1. Penurunan Biaya Produksi (Rolling Cost)

2. Penurunan Harga Pokok Produksi (HPP)

3. Meningkatkan daya saing produk

4. Meningkatkan pendapatan perusahaan

Perlu dilakukan evaluasi kembali akan efektifitas dari implementasi visual planning pada Direktorat Produksi dengan mengukur tingkat pencapaian QO setelah implementasi.

\section{DAFTAR PUSTAKA}

Aguinis, H. (2008). Performance Management. 2nd ed., New York, NY: Prentice Hall.

Josefin, B. and Gunilla, W.,2015. Visual Planning: Coordination and Collaboration of Multi-site Teams in Product Development Organisations, Master of Science Thesis in Production Engineering, Sweden:Chalmers University Of Technology

Lindlöf, L. \& Söderberg, B., 2011. Pros and cons of Lean Visual Planning: experiences from four product development organizations.

Min, K.Z.,(2010)., Development of Visual Planning in POSCO and Effective Methodology to Create a High Performance Work Team, Master Thesis, Canada: McGill University

Ronald Mascitelli, 2011. Mastering Lean Product Development: A Practical, Event-Driven Process for Maximizing Speed, Profits, and Quality. Technology Perspectives. 1st edition

Statistical Yearbook (2016), : SEAISI 